\title{
MORFOMETRI LERENG GISIK DI PANTAI TUMPAAN KECAMATAN TUMPAAN KABUPATEN MINAHASA SELATAN
}

\author{
(Beach Gradient Morphometric at Tumpaan Shore, District of Tumpaan South \\ Minahasa Regency)
}

\author{
Febrik Namoua $^{{ }^{*}}$, Hermanto W. K. Manengkey ${ }^{1}$, Royke M. Rampengan ${ }^{1}$. \\ 1. Program Studi IImu Kelautan, Fakultas Perikanan dan Ilmu Kelautan, Universitas Sam \\ Ratulangi, Manado. \\ *e-mail : febriknamoua@yahoo.co.id
}

Beach is landform the characterized by sedimentary material such as sand or gravel and can also be used by humans as a moor place for fishermen, the fishing industry, tourism and residential building in around the beach area. This study was conducted in the District Tumpaan, South Minahasa regency of North Sulawesi, on the sampling site was at Amurang bay. The aim of research was to observing the change slope distribution, erosion and deposition. Obtained data was using primary or direct observation, following measurements of beach slope by using the portable tools that fit the form of water, rope, meter measurement. In association with the measurement methods that used in research we applied a descriptive method to examine changes morphometric of Tumpaan slope in two different times e.g. February, 19 and September 12, 2015. Further data beach morphometric measurement processed by using computer-assisted programs and other software applications e.g. Arc-Gis. The results of this study using Arc-Gis readable values of slope distribution and the distribution of deposition and erosion on the beach in the observation area. Based on the results of data processing slope distribution on February 19, 2015 the most gentle slope that was $26.96 \%$, whereas on September 12, 2015 most heavily slanted slopes i.e. $30.18 \%$, distribution erosion was $13.440 .584,39 \mathrm{~m}^{3}$ while deposition was $9.053 .553,11 \mathrm{~m}^{3}$. From the processed data, the deposition process was happen in February 2015 while the erosion process was happen in September 2015.

Keywords : Description, Beach, Morphometric, Distribution, Erotion.

Gisik adalah salah satu bentuklahan yang dicirikan oleh material sedimen berupa pasir atau kerikil, gisik juga dapat dimanfaatkan oleh manusia sebagai tempat penambatan perahu para nelayan, industri perikanan, pariwisata, dan bangunan pemukiman di sekitar lahan gisik. Penelitian ini, dilakukan di pantai Tumpaan Kecamatan Tumpaan Kabupaten Minahasa Selatan Provinsi Sulawesi Utara, kawasannya tepat di teluk Amurang. Serangkaian penelitian ini dengan tujuan mengobservasi perubahan kemiringan lereng gisik terhadap sebaran kemiringan lereng serta deposisi dan erosi. Data diperoleh dengan menggunakan data primer atau diamati secara langsung, selanjutnya untuk mendapatkan data hasil penelitian dilakukan pengukuran kemiringan lereng gisik dengan menggunakan alat rakitan maupun alat portabel yang berupa water pas, tali, meteran. Sehubungan dengan pengukuran tersebut metode yang digunakan dalam kegiatan penelitian yaitu menerapkan metode deskriptif yang dilakukan berdasarkan tujuan, untuk menelaah perubahan morfometri lereng gisik pantai Tumpaan dalam dua waktu yang berbeda yaitu 19 Februari 2015 dan 12 September 2015. Data hasil pengukuran morfometri gisik, selanjutnya data diolah menggunakan komputer dengan perangkat lunak surfer 8 serta perangkat lunak Arc-Gis. Dengan Arc-Gis dapat dibaca nilai-nilai sebaran kemiringan lereng serta sebaran deposisi dan erosi pada lahan gisik yang di telaah. Berdasarkan data hasil pengolahan sebaran kemiringan lereng pada 19 Februari 2015 terkriteria lereng landai yaitu $26,96 \%$ dan pada 12 September 2015 terkriteria lereng sangat miring yaitu $30,18 \%$. Sedangkan sebaran erosi $9053553,11 \mathrm{~m}^{3}$ dan deposisi $13440584,39 \mathrm{~m}^{3}$.

Kata Kunci : Deskripsi, Gisik, Morfometri, Sebaran, Erosi 


\section{PENDAHULUAN}

Pemanfaatan ruang di daerah
pantai, harus didukung oleh
pemahaman yang baik mengenai ruang
pantai itu sendiri. Salah satu
pemahaman yang penting dalam
rangka pemanfaatan ruang di daerah
pantai adalah menyangkut bentuklahan
pantai. Menurut Davis (1991)
geomorfologi pantai adalah suatu
pengkajian tentang bentuklahan pantai,
perkembangan proses-proses yang
berlangsung, dan perubahan-
perubahan yang terjadi pada saat
sekarang ini. Pengertian tersebut
menjelaskan lingkup kajian
geomorfologi pantai, juga menunjuk
pada objek kajian yang mencakup
seluruh ruang di pantai.
Keberadaan daerah pantai sebagai daerah peralihan, menjadikan kawasan ini sebagai tempat yang sangat kompleks. Kompleksnya proses yang terjadi di daerah pantai ditimbulkan oleh bertemunya kekuatan yaitu berasal dari daratan maupun dari lautan serta hasil interaksi dua kekuatan tersebut. Menurut Dahuri dkk (1996) daerah pantai merupakan suatu daerah pertemuan antara darat dan laut, ke arah darat sejauh masih mendapat pengaruh laut (angin laut, pasut dan perembesan air laut) dan ke arah laut sejauh masih mendapat pengaruh proses alam yang terjadi di darat.

terjadi di pantai mengakibatkan bentuklahan di kawasan ini sangat beragam. Sebaliknya keberadaan bentuklahan di pantai ditentukan oleh kombinasi faktor alam yang bekerja pada ruang tersebut. Dengan demikian keberadaan bentuklahan pada ruang pantai merefleksikan kerja faktor alam dalam ruang pantai itu sendiri.

Gisik adalah salah satu bentuklahan yang sering dijumpai di ruang pantai, gisik (beach) dipahami sebagai salah satu bentuklahan di pantai yang bermaterial lepas dan akan tergenang pada saat air pasang serta terbuka manakala air surut. Menurut Pethick (1997), gisik adalah salah satu bentuklahan di pantai yang dicirikan oleh hamparan sedimen berupa pasir atau kerikil.

Gisik berperan penting dalam kaitannya dengan pemanfaatan ruang di pantai. Peran alami gisik terhadap garis pantai adalah secara alami gisik ditujukan tidak saja oleh posisi sebagai pembatas antara laut dan darat, namun juga oleh kemampuannya dalam meredam aksi laut yang berpeluang menggerus daratan sebagaimana diperankan oleh energi gelombang dan arus (Gross 1993).

Salah satu kawasan pantai yang secara aktual memiliki lahan gisik adalah pantai Tumpaan Kabupaten Minahasa Selatan Provinsi Sulawesi Utara. Kawasan pantai ini terdapat di Teluk Amurang yang secara aktual telah dimanfaatkan secara beragam oleh manusia yaitu sebagai tempat penambatan perahu, kawasan industri, pemukiman penduduk, pariwisata dan bangunan di sekitar lahan gisik. Keberadaan gisik di sepanjang pantai Tumpaan memiliki peran yang penting bukan hanya dari aspek pemanfaatan, tetapi juga dari aspek perlindungan pantai. Gisik di sepanjang pantai Tumpaan secara alami mereduksi aktivitas erosi oleh kekuatan laut, sehingga menjadi pelindung alami terhadap keberadaan pemukiman di kawasan ini yang umumnya letaknya dekat garis pantai.

Berdasarkan dari uraian sebelumnya maka kehadiran gisik di daerah pantai perlu ditelaah secara cermat guna menyediakan informasi mengenai ruang lahan gisik untuk memungkinkan penggunaannya secara berkelanjutan.

Penelitian ini bertujuan mengobservasi dan mendiskripsikan lereng gisik di pantai Tumpaan dan menganaliperubahan kemirimgan lereng gisik serta daerah erosi dan deposisi pada gisik yang ditelaah. 


\section{METODE PENELITIAN}

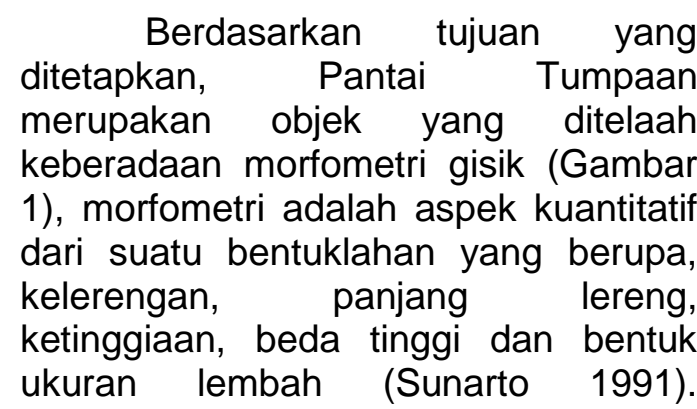
Penelitian ini, dengan menerapkan metode deskriptif terhadap perubahan sebaran kemiringan lereng dan sebaran deposisi dan erosi. Penerapan metode tersebut ditempuh dalam kegiatan survei pantai selanjutnya serangkaian kegiatan analisis data yang dilaksanakan di ruang Laboratorium Geomorfologi Pantai FPIK UNSRAT untuk pengolah kata dan penyajian data hasil penelitian dengan menggunakan bantuan fasilitas komputer. Dalam hal ini, penelitian dikerjakan untuk mengungkapkan variabel morfometri gisik dengan selang waktu yang berbeda pada gisik di pantai Tumpaan yaitu pada 19 Februari 2015 dan 12 September 2015.

Pengambilan data menggunakan metode survei dan pengambilan data tersebut dilakukan secara langsung di daerah lokasi penelitian dengan berbagai peralatan berupa alat rakitan yaitu water pas, tali, bambu dan meteran untuk memperoleh nilai $X, Y$ dan $Z$.

Data penelitian diolah dan disajikan dalam bentuk tabel, grafik dan gambar dengan menggunakan bantuan komputer. Pekerjaan ini diawali dengan penanganan dan pengolahan data hasil pengukuran dengan bantuan komputer dan hasilnya digambarkan dalam bentuk peta kontur adapun pengolahan data menggunakan perangkat lunak surfer 8 dan perangkat lunak Arc-Gis. Selanjutnya, hasil penggambaran peta kontur pada surfer menjadi masukan untuk dilakukan analisis spasial menggunakan perangkat lunak ARCGIS. Pada Arc-Gis, analisis spasial yang dilakukan adalah memetakan dan

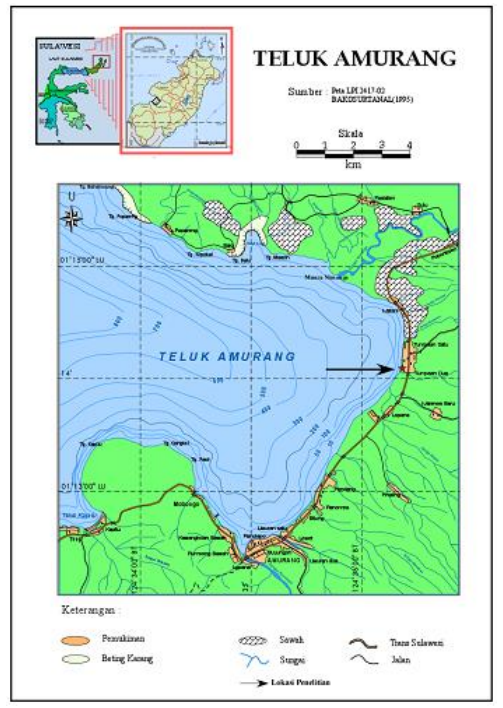

Gambar 1. Lokasi Penelitian

menghitung sebaran kemiringan lereng, serta tumpang susun peta kontur untuk mendeskripsikan sebaran daerah erosi dan deposisi.

\section{HASIL DAN PEMBAHASAN}

Berdasarkan hasil pengukuran morfometri gisik pada lokasi penelitian dengan menggunakan metode deskriptif yang telah diuraikan terdahulu, sejumlah data yang telah diperoleh diolah dan dianalisis dengan menggunakan bantuan komputer perangkat lunak surfer 8 serta perangkat lunak Arc-Gis. Dalam mencapai tujuan yang telah ditetapkan, observasi pengambilan data dilakukan dalam selang waktu yang berbeda dilihat pada periode umur bulan (bulan mati) dimana pengambilan data tersebut dilakukan pada tanggal 19 Februari 2015 dan 12 September 2015. Dari data hasil pengukuran ditampilkan pada Gambar 2 dan 3.

Berdasarkan hasil pengolahan

data bulan Februari 2015 dan September 2015 dapat disadap dengan menggambarkan lereng gisik bentuk garis kontur. Garis kontur adalah garis yang menghubungkan titik-titik yang mempunyai ketinggian yang sama, yang terukur dari darat sampai ke arah laut. Makin jauh jarak antara kontur 


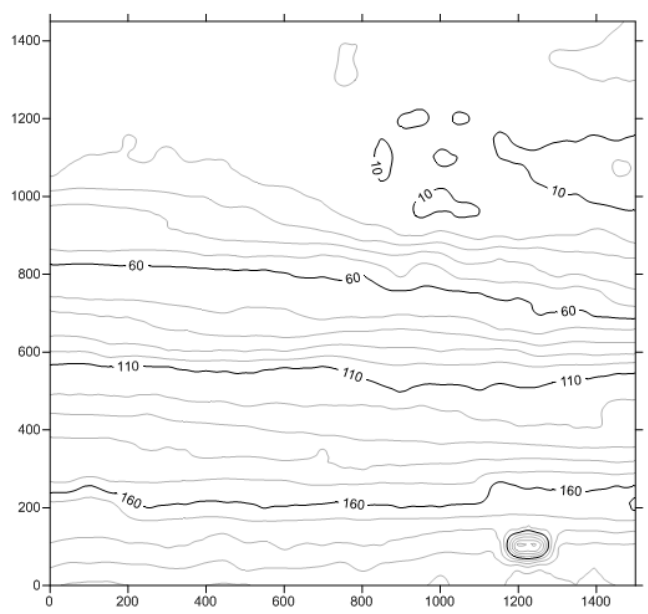

Gambar 2. Pemetaan Topografi Gisik Lokasi Penelitian di Pantai Tumpaan Berdasarkan Pengukuran Yang Dilakukan Pada 19 Februari 2015.

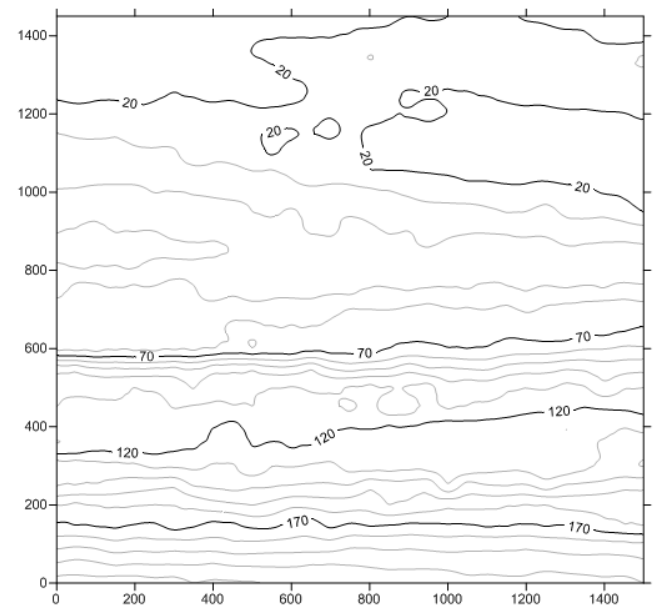

Gambar 3. Pemetaan Topografi Gisik Lokasi Penelitian di Pantai Tumpaan Berdasarkan Pengukuran Yang Dilakukan Pada 12 September 2015.

menunjukkan daerah tersebut semakin landai sebaliknya makin rapat garis kontur satu dengan yang lain menunjukkan daerah tersebut makin miring. Selanjutnya nilai-nilai grid yang terdapat dalam peta kontur adalah nilai $Z$ dari data hasil pengukuran kemiringan lereng gisik.

Data hasil pengukuran morfometri diolah menggunakan perangkat lunak Arc-Gis sebagai salah satu program yang membantu dalam

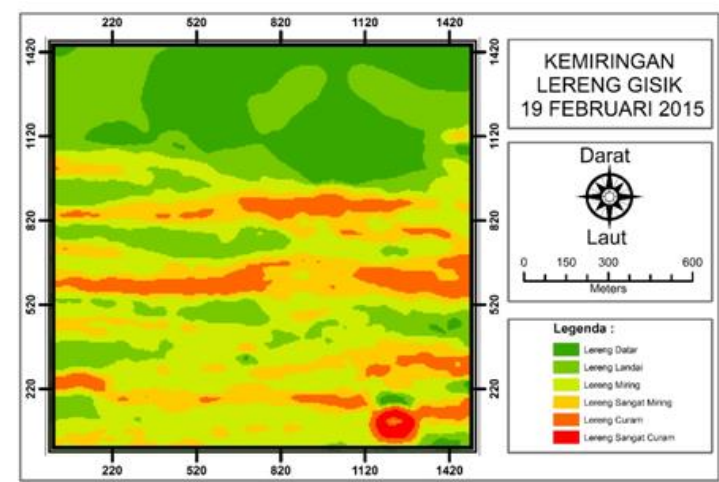

Gambar 4. Sebaran Kemiringan Lereng Gisik Pengukuran 19 Februari 2015.

pengolahan data penelitian berupa sebaran kemiringan lereng gisik yang dilakukan pada 19 Februari 2015 Gambar 4.

Bertolak dari Tabel 1 dan mengacu pada klasifikasi sebaran kemiringan lereng gisik 19 Februari 2015, pada peta sebaran kemiringan didominasi lereng landai yaitu 26,96 \% dan sebaran kemiringan lereng yang terkecil terdapat pada warna merah yaitu lereng sangat curam $0,87 \%$.

Jika dibandingkan dengan data hasil pengukuran serta hasil pengolahan data sebaran kemiringan lereng gisik pada 12 September 2015, seperti Gambar 5.

Tabel 1. Sebaran Kemiringan Lereng

\begin{tabular}{ccccc}
\hline No & $\begin{array}{c}\text { Kelas } \\
\text { Kemiringan } \\
\text { Lereng }\end{array}$ & $\begin{array}{c}\text { Kode } \\
\text { Crid }\end{array}$ & indeks & $\begin{array}{c}\text { Persentasi } \\
\%\end{array}$ \\
\hline 1 & $\begin{array}{c}\text { Lereng Datar } \\
\text { Lereng }\end{array}$ & 1 & 43 & 19,37 \\
2 & $\begin{array}{c}\text { Landai } \\
\text { Lereng Miring } \\
\text { Lereng }\end{array}$ & 2 & 44 & 19,82 \\
& $\begin{array}{c}\text { Sangat } \\
\text { Miring }\end{array}$ & 4 & 44 & 19,82 \\
4 & $\begin{array}{c}\text { Lereng } \\
\text { Curam }\end{array}$ & 5 & 16 & 30,18 \\
& $\begin{array}{c}\text { Lereng } \\
5\end{array}$ & & & 7,21 \\
& $\begin{array}{c}\text { Sangat } \\
\text { Curam } \\
6\end{array}$ & 6 & 8 & 3,60 \\
& Jumlah & & 222 & 100 \\
\hline
\end{tabular}

Gisik 19 Februari 2015. 


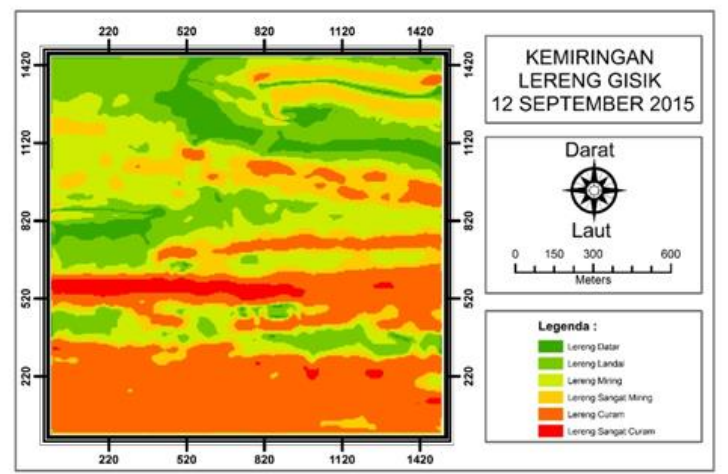

Gambar 5. Sebaran Kemiringan Lereng Gisik Pengukuran 12 September 2015.

Tabel 2. Sebaran Kemiringan Lereng Gisik 12 September 2015.

\begin{tabular}{|c|c|c|c|c|}
\hline No & $\begin{array}{l}\text { Kelas } \\
\text { Kemiringan } \\
\text { Lereng }\end{array}$ & $\begin{array}{l}\text { Kode } \\
\text { Crid }\end{array}$ & Indeks & $\begin{array}{c}\text { Persentasi } \\
\%\end{array}$ \\
\hline 1 & $\begin{array}{l}\text { Lereng } \\
\text { Datar }\end{array}$ & 1 & 19 & 16,52 \\
\hline 2 & $\begin{array}{l}\text { Lereng } \\
\text { Landai }\end{array}$ & 2 & 31 & 26,96 \\
\hline 3 & $\begin{array}{l}\text { Lereng } \\
\text { Miring }\end{array}$ & 3 & 14 & 12,18 \\
\hline 4 & $\begin{array}{l}\text { Lereng } \\
\text { Sangat } \\
\text { Miring }\end{array}$ & 4 & 29 & 24,34 \\
\hline 5 & $\begin{array}{l}\text { Lereng } \\
\text { Curam }\end{array}$ & 5 & 22 & 19,13 \\
\hline 6 & $\begin{array}{l}\text { Lereng } \\
\text { Sangat } \\
\text { Curam }\end{array}$ & 6 & 1 & 0,87 \\
\hline & Jumlah & & 115 & 100 \\
\hline
\end{tabular}

Berdasarkan Tabel 2, sebaran kemiringan lereng gisik dari hasil pengukuran serta hasil pengolahan data pada 12 September 2015, didominasi lereng sangat miring yaitu $30,18 \%$, sedangkan sebaran yang paling terkecil terdapat pada lereng sangat curam yaitu $3,60 \%$. Hal ini, dibuktikan bahwa pada bulan September 2015 sebaran kemiringan lereng gisik lebih besar dibandingkan pada bulan Februari 2015.

Penelitian dilakukan pada lahan gisik yang diobervasi dapat menunjukan volume sebaran deposisi dan erosi pantai terlihat pada Gambar 6.

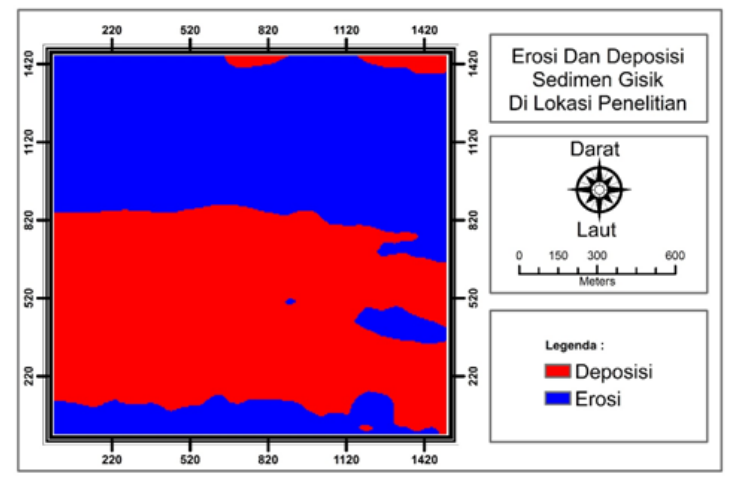

Gambar 6. Sebaran Daerah Erosi dan Deposisi Pada Gisik Lokasi Penelitian.

Berdasarkan Gambar 6 memperlihatkan lokasi observasi terdapat area deposisi maupun erosi. Area deposisi ditandai dengan warna merah sedangkan erosi ditandai dengan warna biru. Analisis spasial ini menggunakan perangkat lunak Arc-Gis. Dalam analisis spasial ini dapat memetakan sebaran kemiringan serta menghitung volume deposisi dan erosi suatu lahan. Hasil tersebut disajikan dalam Tabel 3.

Berdasarkan data hasil pengolahan pada 19 Februari 2015 dan 12 September 2015, ditabulasikan dalam perangkat lunak Arc-Gis dengan bentuk peta kontur seperti Gambar 7 .

Gambar peta kontur merupakan tampilan yang lebih nyata mengenai keberadaan lahan gisik yang diobservasi. Berdasarkan Gambar 7, peta kontur ini pada penggunaan perangkat lunak Arc-Gis tingkat lanjut dapat disesuaikan graduasi warna dengan kemiringan lereng ataupun kaitannya dengan variabel yang lain.

Tabel 3. Sebaran Volume Deposisi dan Erosi.

\begin{tabular}{ccc}
\hline No & Proses & Volume Area $\left(\mathrm{m}^{3}\right)$ \\
\hline 1 & Erosi & 9053553,11 \\
2 & Deposisi & 13440584,39 \\
\hline
\end{tabular}




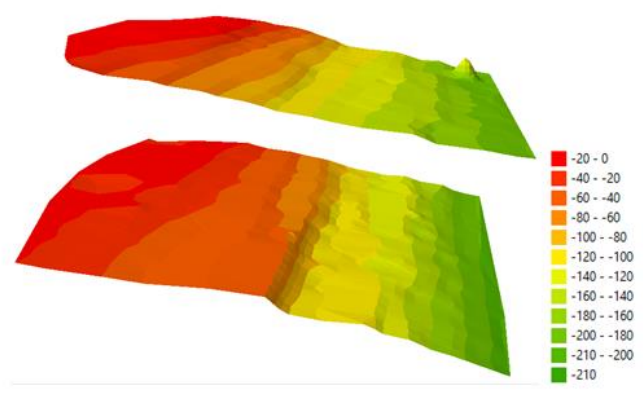

Gambar 7. Tumpang Susun Profil Gisik Pengukuran 19 Februari (Atas) dan Pengukuran 12 September 2015 (Bawah).

Pada peta kontur Gambar 7, tumpang susun profil bagian atas adalah hasil pengukuran pada bulan Februari 2015 dan bagian bawah hasil pengukuran bulan Septembar 2015. Peta kontur bagian atas warna merah pada bagian darat hasil pengukuran bulan Februari 2015 menunjukkan kemiringan lereng lebih landai jika dibandingkan hasil pengukuran bulan September 2015 kemiringan terlihat miring.

\section{KESIMPULAN}

Berdasarkan hasil pengolahan data morfometri gisik, pada lokasi penelitian di pantai Tumpaan diperoleh kesimpulan sebagai berikut :

> Pada pengukuran Februari 2015 kriteria lereng yang terukur adalah lereng datar $16,52 \%$, lereng landai $26,96 \%$, lereng miring $12,18 \%$, lereng sangat miring $24,34 \%$, lereng curam $19,87 \%$ dan lereng sangat curam $0,87 \%$.

> Pengukuran pada September 2015 kriteria lereng yang terukur adalah lereng datar $19,37 \%$, lereng landai $19,82 \%$, lereng miring $19,82 \%$, lereng sangat miring $30,18 \%$, lereng curam $7,21 \%$ dan lereng sangat curam 3,60\%.

- Pada lahan gisik lokasi penelitian proses dominan yang terjadi antara
2 selang waktu pengukuran adalah deposisi sedimen.

\section{DAFTAR PUSTAKA}

Dahuri, R., Rais, J., Ginting; S.P., Sitepu, M. J. 1996. Pengelolaan Sumberdaya Wilayah Pesisir dan Lautan Secara Terpadu. Cetakan Pertama. PT Pradnya Paramita. Jakarta.

Davis Jr., R.A. 1991. Oceanography, an Introduction to The Marine Environments, Wm. C. Brow Publisher.

Gross, M.G. 1993 Oceanography. A Viev of Earth. Sixth Edition.

Pethick, J. 1997. An Introduction to Coastal Geomorphology. Edward Arnold. London.

Sunarto. 1991. Geomorfologi Pantai. Pusat Antar Universitas. Universitas Gadjah Mada. Yogyakarta. 